Section 64 of the Factories Act, 1937. The circumstances in which reports are required are detailed, and copies of the prescribed forms are appended to the booklet and also of the tables used for classifying the information. The booklet describes in detail how this information is examined, classified and given a coding to permit subsequent analysis.

\section{Grants for Field Work in Natural History}

Groups of local naturalists often find themselves held up for lack of specialist advice on how to tackle their problems. To help its members, the Council for Nature approached the Carnegie U.K. Trust, which has now agreed to set aside a fund from which it will make grants to approved societies for assistance with field work. These grants will be made on recommendations submitted by the Council for Nature and will be contributions towards expenditure incurred in carrying out specific projects that give amateurs experience of field work in natural history under skilled direction. Approved expenditure is likely to include fees paid to experts for instruction and leadership, the incidental expenses of such people and the cost of essential equipment subject to certain conditions. Grants will not be available for the expenses incurred by members of societies taking part in any scheme or for the general support of a society. Full particulars of the conditions for the award of grants can be obtained from the Carnegie U.K. Trust, Comely Park House, Dunfermline, Fife, or from the Council for Nature, 41 Queen's Gate, London, S.W.7.

\section{The Wellcome Trust :}

\section{Grants for Medical Research}

During the six months from March 1 to August 31 the Wellcome Trustees accepted the following applications for major grants to assist medical research. Together with smaller grants totalling $£ 41,000$, and Wellcome research travel grants, totalling $£ 17,000$, the allocations by the Trustees in this period exceeded $£ 420,000$. The grants were allocated as follows: $\mathfrak{f 5 0 , 0 0 0}$ to the Middlesex Hospital Medical School, University of London (Prof. C. A. Keele), for a suite of Wellcome Research Laboratories in the Pharmacology Department of the new Medical School building; $£ 50,000$ to the Massachusetts General Hospital, Boston, to establish a Wellcome research professorship for ten years; $£ 61,000$ to the Medical Research Council, to construct a laboratory and housing accommodation for an Epidemiological

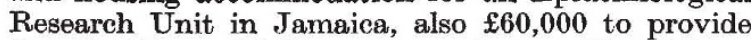
five Sir Henry Wellcome research travelling fellow. ships for five years; $£ 40,000$ to McGill University, Montreal, Canada, to extend the support of the Wellcome Research Department of Anæsthesia for a further five years; $£ 17,000$ to the University of Pennsylvania, to extend the support of the Wellcome associate professorship of research in anæsthesiology for a further three years ; $£ 16,000$ to Trinity College, Dublin (Mr. K. M. Shaw), to construct and equip an experimental surgery unit and an animal house; $£ 16,300$ to the University of Oxford (Sir George Pickering), to construct an animal house for the use of workers in the Department of the regius professor of medicine ; $£ 6,000$ to the Postgraduate Medical School, University of London (Prof. J. McMichael), to equip a cardiac catheterization research laboratory in the Department of Medicine; $£ 10,000$ to the University of Birmingham, Department of Biochemistry (Prof. S. V. Perry), for equipment to investigate the nature and functions of the proteins of brain and muscle; $£ 5,500$ to St. Mary's Hospital Medical School, University of London (Prof. R. R. Porter), for an analytical ultracentrifuge to investigate the structure of antigens and antibodies.

In addition the Trustees made grants totalling $£ 21,800$ for special research apparatus of various kinds to Prof. R. Woolmer, Department of Anæsthesia, Royal College of Surgeons of England; Dr. G. A. Kerkut, University of Southampton; Mr. H. A. Sissons, Institute of Orthopædies, University of London; the Agricultural Research Council's Virus Research Unit, Cambridge ; Dr. K. S. Dodgson, Department of Biochemistry, University College of South Wales and Monmouthshire; Prof. O. L. Wade, The Queen's University, Belfast; Prof. G. A. H. Buttle, School of Pharmacy, University of London; Prof. J. W. Howie, University of Glasgow ; and Prof. H. Heller, University of Bristol. A grant of $£ 1,000$ to purchase special equipment for highaltitude research was made to Dr. L. G. C. E. Pugh, physiologist to the Himalayan Scientific and Mountaineering Expedition, 1960-61.

\section{Announcements}

Prof. Arne Tiserius, of the University of Uppsala, Nobel laureate in chemistry (1948), has been appointed president of the Nobel Foundation.

THe Medical Research Council has recently established the following new research units : the Gastroenterology Research Unit at the Central Middlesex Hospital under the direction of Dr. E. N. Rowlands; and the Unit for Research on the Chemical Pathology of Mental Disorders in the Department of Physiology, University of Birmingham, under the honorary direction of Prof. I. E. Bush.

The Institute of Biology, with the support of the Eugenics Society, has instituted an annual Darwin Memorial Lecture in human biology. The first lecture will be given by Dr. C. E. Ford of the Medical Research Council's Radiobiological Research Unit on "The Cytogenetics of Sex in Man". The lecture will be given in the lecture hall of the British Museum (Natural History), Cromwell Road, S.W.7, at 5.15 p.m. on November 23 and is open to the public.

THE annual exhibition of the Institute of Physies and the Physical Society will be held at the Royal Horticultural Society's Old and New Halls, Westminster, London, S.W.1, during January 16-20, 1961. During the exhibition, the following discourses and demonstration lectures will be given in the New Hall : January 17, "Hydrodynamics Research", by F. S. Burt (Admiralty Research Laboratory); January 18, "The Physics of the Ocean", by Dr. G. E. R. Deacon (National Institute of Oceanography); January 19, "Some Physical Problems in Travelling at Supersonic Speed", by Dr. F. P. Bowden (Laboratory for the Physics and Chemistry of Solids, Cambridge). Further information and tickets can be obtained from the Institute of Physics and the Physical Society, 47 Belgrave Square, London, S.W.1.

ErRatum. We regret that in the communication entitled "Evidence for the Identity of Natriferin, the Frog Water-Balance Principle and Arginine Vasotocin", by Prof. Wilbur H. Sawyer, in Nature of September 17, p. 1030 , there is a mistake in the table; the right-hand heading should read: "Activities (U./mgm. dry weight)". 